This article was downloaded by: [University of Sydney]

On: 14 March 2015, At: 00:40

Publisher: Routledge

Informa Ltd Registered in England and Wales Registered Number: 1072954

Registered office: Mortimer House, 37-41 Mortimer Street, London W1T

3J H, UK

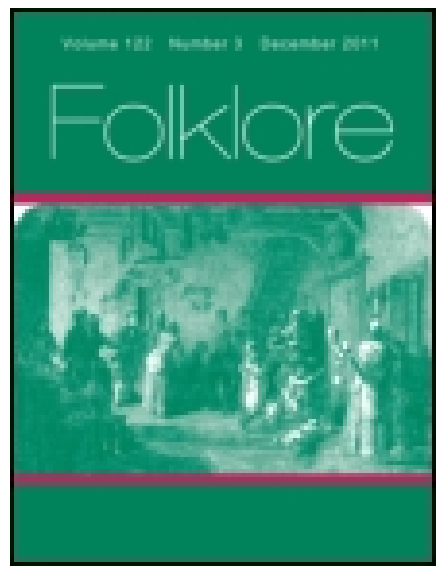

\title{
Folklore
}

Publication details, including instructions for authors and subscription information:

http:// www. tandfonline.com/loi/ rfol20

\section{Animal Superstitions and Totemism.}

N. W. Thomas

Published online: 14 Feb 2012.

To cite this article: N. W. Thomas (1900) Animal Superstitions and Totemism., Folklore, 11:3, 227-267, DOI: 10.1080/ 0015587X. 1900.9719953

To link to this article: http:// dx.doi.org/ 10.1080/ 0015587X. 1900.9719953

\section{PLEASE SCROLL DOWN FOR ARTICLE}

Taylor \& Francis makes every effort to ensure the accuracy of all the information (the "Content") contained in the publications on our platform. However, Taylor \& Francis, our agents, and our licensors make no representations or warranties whatsoever as to the accuracy, completeness, or suitability for any purpose of the Content. Any opinions and views expressed in this publication are the opinions and views of the authors, and are not the views of or endorsed by Taylor \& Francis. The accuracy of the Content should not be relied upon and should be independently verified with primary sources of information. Taylor and Francis shall not be liable for any losses, actions, claims, proceedings, demands, costs, expenses, damages, and other liabilities whatsoever or howsoever caused arising directly or indirectly in connection with, in relation to or arising out of the use of the Content.

This article may be used for research, teaching, and private study purposes. Any substantial or systematic reproduction, redistribution, reselling, loan, sub-licensing, systematic supply, or distribution in any form to anyone is 
expressly forbidden. Terms $\&$ Conditions of access and use can be found at http://www.tandfonline.com/page/terms-and-conditions 


\section{ANIMAL SUPERSTITIONS AND TOTEMISM.}

BX N. W. THOMAS, M.A.

(Read at Meeting of April 25th, 1900.)

[The MS. notes (indicated by a $\dagger$ ) are from the following ladies and gentlemen, to whom I here offer my most sincere thanks for their assistance:

Frau Eysn, Salzburg; Oberleutnant z. S. Fischer, Kiel; Herr Gander and Prof. Jentsch, Guben; Herr Gutekunst, Reutlingen; Frau, Fräulein, and Fräulein Greta Meyersahm, Kiel ; Herr Lorenzen, Neumünster; Herr C. Stinde, Leusahn. My especial thanks are due to Dr. Feilberg for many citations from books inaccessible to $\mathrm{me}$, and to Herr Jühling for MS. contributions and the advance sheets of his valuable work, Tiermedizin. I wish also to acknowledge my great indebtedness to Mr. Gomme; the Irish evidence in the first section is drawn entirely from his valuable papers in the Archaological Review, on which I based my further researches.

A bibliography of the works most frequently quoted will be found at the end of the article.]

TOTEMISM has been found as a living cult in only two considerable areas of the world's surface-North America and Australia. For the majority of the human race it is, at most, an "überwundener Standpunkt," perhaps not even that, for authoritative voices have been raised to deny both its extensive distribution in the past and its importance in the history of religion.

The evidence for the former existerice of Totemism, as of all other, forgotten stages of man's development, must be sought in survivals. A survival is a belief, custom, or institution whose origin and meaning are lost; its explanation is to be found sometimes in history, sometimes in those prehistoric days whose history has to be written by the aid of folklore.

In speaking to this society I need not do more than allude 
to the fact that the customs and beliefs of European peasants give us a picture, incomplete perhaps, but still unmistakable, of a highly primitive form of religion. Mannhardt's researches into agricultural customs have placed this beyond question. These customs have subsisted virtually unchanged during a relatively long period, if we take the life of the individual as our standard. In another sense agriculture is modern. Our present methods of cultivation have ousted, over a large part of the old world, a more archaic mode of culture; our present cereals have supplanted millet, which most of us know only in fairy tales. 'This displacement of millet by cereals is, measured in years, infinitely remote, if we may judge by the slow decline of millet-cultivation in historic times. Infinitely more remote, however, is the introduction and spread of millet itself, which is found in regions that corn has never reached. Before this again, we must assume a period of uncertain duration when cultivated plants were yet unknown, and during which man spread over the world, subsisting on roots and fruits in the earlier stages, in the later on the chase and other methods of procuring food which presuppose a certain equipment; and in the seasons when wild animals were scarce, returning, perhaps, to the earlier mode of life.

The corn era is then relatively short. Compared with it the preceding periods are infinitely long. But, if the peasant has conserved his archaic agricultural religion, it does not seem hopeless to look for relics of still earlier cults in the customs of those who have shown themselves so inaccessible to the influences of civilisation: If Christianity and the corn-spirit have lived side by side for a thousand years and more, the stages which preceded agriculture will surely have left their traces, less distinctly it may be, but yet clearly enough for those who know how to read them, on the life of the European peasant of to-day.

As a natural result of the external influences to which; more than any other feature of the cult, it has been exposed, the 
social side of Totemism will be found, we may expect, to be relatively far less important in the survivals, than the religious side, which is the attitude rather of the individual man to the sacred animal. In other words, the survivals of Totemism in Europe must be sought in the animal ${ }^{1}$ superstitions and not in the marriage customs of the uncivilised or little civilised European peasant. These superstitions, adopting in - part the classification made by Mr. Gomme of Dr. Frazer's Totemism, ${ }^{2}$ I arrange under the following heads :

\section{I.-Totemic, op Quasi-Totemic.}

I. Descent from the totem.

2. Taboos (a) of killing the animal ; $(b)$ of eating, touching, or using it; $(c)$ of seeing it; $(d)$ of using the ordinary name.

3. Petting the totem-animal.

4. Burying the dead totem-animal.

5. Respect paid to the totem-animal.

6. (a) Lucky animals, (b) unlucky animals.

7. Adoption of $(a)$ totem-marks, (b) totem-names, (c) totem-dress.

8. (a) Birth, (b) marriage, (c) death-customs.

9. Magical powers derived from the totem.

Io. Local cults.

II. Customary rents.

Following Mr. Gomme, I call the first nine of the above superstitions "categoric"; the animals to which they apply I call "totem objects."

\section{II.-Animals Used in Augury and Magic.}

As a matter of convenience I class separately the beliefs about ominous animals. This section might, however; as I

In view of the fact that many tribes have none but animal totems, the absence of totemistic plant superstitions would partly tell against my argument.

Archroological Review, iii., 21 7, $35^{\circ}$ ff. 


\section{Animal Superstitions and Totemism.}

endeavoured to show in a discussion of Welsh superstitions, ${ }^{1}$ be justifiably included among the "categorics," in spite of the apparent multiplicity of possible origins of this ominous character of animals. I include in this division further the use of the animal in (a) magic, $(b)$ medicine, (c) divination.

\section{III.-Annual Ceremonies.}

I. Sacrifice ; 2. Communion with the sacred animal.

This analysis is, I think, fairly exhaustive; it is in the main based on the superstitions actually found among totems. There are probably few, if any, European superstitions relating to animals that cannot be classified according to the above scheme. As evidence of the former existence of totemism in Europe, the sections are, however, of unequal value, and I propose to deal with the more important ones only.

This will naturally not permit me to show the cumulative character of the evidence with regard to single animals. More important, however, than this cumulative character is the local distribution of the superstitions with which I deal; and I prefer to emphasize this feature rather than to analyse all the superstitions relating to a small number of animals.

I lay down at the outset the principle that no theory of the origin of animal superstitions can disregard this local character of the beliefs; one parish respects an animal and will not kill it; their neighbours regard the same animal with indifference, and even aversion. Even where no such striking contrast is present, the local character of the superstition is always very prominent. Yet in spite of this we find such an agreement between distant regions, both in custom and belief, as to exclude the idea of a purely local origin of the superstitions. Special explanations, alluring enough when only the single case is considered, are manifestly.impossible when we have to deal with a great mass of

'Revue de l'Histoire des Réligions, xxxviii., No. 3. 
facts presenting the same features and gathered over a wide area. I emphasize at the outset the importance of this local character of beliefs, which are, in another sense, very far from being local, since they are distributed over all Europe.

The portions of the above scheme dealt with in this paper are the following:-

1. Totemic and Quasi-Totemic.

I. Descent from the totem animal.

IA. Quasi-Totemic superstitions and tales.

(a) Stories of Animal Ancestors, \&c.

i. Animal births.

ii. Swan maiden type.

iii. Midas type; (a) Sagas; $(\beta)$ Local legends.

iv. Helpful animals.

v. Baby-bringers.

(b) Animal Form.

i. "Soul-animals."

ii. "Witch-animals."

iii. Animal transformed man.

iv. Animal can assume human form.

(c) Animal as Life-Index.

(d) Animal Genius.

i. Aettar-fylgia.

ii. Fylgia.

(e) Animal Substitutes in Witchcraft.

(f) Werwolves.

2. The Animal tabooed or sacrosanct.

(a) Animals which may not be killed.

(b) Animals which may not be eaten, touched, or used.

3. The animal kept in captivity for magical or other superstitious purposes or fed or otherwise petted.

4. Burying the dead animal.

9. Magical powers derived from the animal.

II. ANimals uSEd IN AUgury AND Magic.

III. Annual Ceremonies.

1. Sacrifice.

(a) The Hunt. 
232 Animal Superștitions and Totemism.

(b) The Hahnenschlag.

(c) The Simple Form.

i. First seen, killed.

ii. Killed as talisman (a) on given date, iii. $(\beta)$ at given season; $(y)$ at all seasons.

(d) Torture Form.

(e) Precipice Form.

$(f)$ Fire Form.

1A. Procession.

2. Communion with the sacred animal.

(a) By Distribution.

(b) By Eating-

i. The animal.

ii. The "animal-cake."

In the form of an appendix to III. 1. I deal briefly with "Games of Sacrifice," including under this name Blind Man's Buff and Cock Warning.

- I now proceed to consider the above points in detail.

I. 1. The section of DESCENT FROM THE TOTEMANimal is, as might have been expected, the one in which I have least evidence to present. Such evidence as there is, however, is incontestable.

There are in the West of Ireland (and, I believe, in some of the Scotch islands) ${ }^{1}$ unmistakable traces of a seal-clan. The clarisman is named after the seal, conceives himself to be of the blood of the eponym animal, and refrains from killing the seal or using it for food if he can possibly avoid it. Accurding to another account, some of the clan (Conneely) were once changed into seals, and since then no Conneely can kill a seal without incurring bad luck. ${ }^{2}$

We find in Ossory an almost parallel case of a local, wolf clan. The account given by Giraldus is interesting as presenting a close resemblance to many werwolf legends.

In a third case-the cat-tribes of Ireland and Scotlandwe have the descent from the eponym animal and its use as a crest.

$$
\text { 'F., vi., 223. 'Journ. Anth. Inst., ii., } 447 .
$$


Other examples are personal —Conaire, Cuchulainn, \&c..

I here pause a moment to emphasize the importance of these facts.

In the case of the seal the distribution of the beliefs is especially noticeable; they are not confined to one locality, nor yet are they universal in the localities in which they are found. Geographically their extension is considerable, but they are held only by certain persons in each district. We have, in fact, the totem-clan itself, save that the social organisation has disappeared.

In the other cases we must recognise rather the local clans into which totem clans tend under certain conditions to pass. Their totemistic origin cannot, however, be questioned, except by those who also dispute this interpretation of the facts about the seal-people and their beliefs.

I need hardly point out that, having once established the former existence of totemism in Britain, we can at once claim for the "categoric superstitions" a very different value. The presence of totemism in the past once admitted, we have only to turn to the table of totem-objects and select those cases in which the evidence is cumulative, to form a provisional list of totems. Given superstitions totemic in form side by side with undoubted survivals of totemism, the onus probandi lies on those who deny the totemic origin of the former.

More or less closely connected with the section just dealt with are a number of superstitions.

IA. Quasi-Totemic Superstitions and Tales.

(a) Stories of Animal Ancestors, etc.

i. Various Märchen found in Hesse and Swabia relate how, an unusual number of children being born at a birth, the mother ordered them to be drowned, with the exception of one; the person to whom this was entrusted was ordered to say that they were dogs. Similar stories are

For the refs. v. Arch. Rev., loc, cit. 
found in Thuringia, Holstein, and elsewhere. Liebrecht conjectures that the original form of the story was one of descent from a dog. This view is supported by the fact that a dog appears in the arms of Hesse, and that the Hessians were termed "Hundhessen" even as late as the I6th century.?

ii. Another type of story is that of the maiden whose skin-dress is carried off by a man, whom she is thus compelled to marry. In view of the facts already mentioned about the seal-clan, it is noteworthy that in the Faroe Islands we find a seal-maiden story. ${ }^{2}$

iiia. To stories of the Midas group it would perhaps be unwise to attach much importance. There can be little doubt that the story came to Brittany and Ireland from the East, where most of the variants are to be found, and where the more archaic form of the story is told. ${ }^{8}$

iii $\beta$. We must not, however, lose sight of the fact that local legends of the same type are found. In Lleyn (Carnarvonshire) it is related that March Amheirchion, the lord of Castell March, had horse's ears, as in Irish story." In the absence of proof it is gratuitous to connect this with the Midas group; possibly the relation is just the reverse, and stories of the Midas group lived where they found the congenial soil of a local legend.

Among legends of this group is that of Siward, who was the son of a bear and had bear's ears. ${ }^{5}$ Brochmail was a tusked king of Powis. 'A tusked or pig-headed birth is still said to appear periodically in the family. ${ }^{6}$

' Zur Volkskunde, p. 21.

- Antiquarisk Tidskrift, 1852, p. 191 ; of. Frazer, Pausanias, iv,, 106, and Hartland, Science of Fairy Tales, for other examples.

Ciszewski, Bajka o Midasowych usgach.

- Y Cymmrodor, vi., 183; I have been unable to identify the source from which Miss Cox, Introduction to Folklore, p. 73, quotes. Keating, History of Ireland, i., 359 .

- Glouceslershire Folklore, p. 12.

- Warter, An Old Shropshire Oak, i., 203; ff. also Rolland, i., r3. For a belief in animal ancestors in Ireland v. Erits, vi., 397. 
(iv.) We find certain animals associated with certain families, such as the spiders with the Bruces; in some cases they are also borne in the arms, and a story is frequently told to explain the connection, according to which the animal once helped a member of the family.1

(v.) To certain animals is assigned the important function of bringing the babies. I do not venture to lay much stress on this sub-section, for someone will probably inquire whether the gooseberry bush from which the English babies come is also a totem. The facts are nevertheless worthy of notice. The best known example is of course the stork; but we find in addition the ladybird fulfilling this office in South Germany; in Bohemia the crow and sometimes the kite; elsewhere the cabbage-butterfly; or the frog, undertakes the task. According to a slightly different account the children come from the hare's nest," or the ass's spring. ${ }^{3}$

\section{(b) Animal Forms, etc.}

(i.) Closely connected with the foregoing sub-section is the belief in the animal form of the soul. In the British Isles we find the following among the soul-animals-ant, butterfly, gull, moth, sparrow, goatsucker, cat, swan, and spider. In Germany we find - the bat, butterfly, bee, cricket, fowl, mouse, peewit, pigeon, raven, snake, swan, toad, and weasel.s: In Rugen it is believed that the seal is descended from drowned human beings. ${ }^{5}$

(iii) Closely connected with the foregoing is the belief in the animal form of human beings, especially, witches. In Germany they appear as bulls, butterflies, cats, donkeys,

'Swainson, Folklore of Bira's, p. 486 ; of. Frazer, Totemism, p. 7 ; of. ii,, $344 f$

"Ploss, Das Kind, i.; 12 ; Schulenburg, Wend. Volkstum, i., 94.

- Mannhardt, Germ. Mythen, p. $41 \mathrm{r}$.

- Meger, passim; Arch. Rev., iii., 226; MS. notes, \&c.

- Mannhardt, Germ. Myth., p. 92; of. Globus, xiv., 287; Jour. Anth. I., ii., 447 . 
goats, deer, horses, hares, eagles, foxes, magpies, moths, pigs, swans, toads, and weasels. ${ }^{1}$ On the authority of Giraldus we may add the wolf in Ireland, and on that of Saxo, the walrus in Norway. The facts admit, however, of another explanation, to which I shall refer later.

(iii.) Widely distributed also is the correlative of this belief. In some cases animals are regarded as human beings under a curse.

In the Isle of Man the wren is said to be a transformed fairy $;^{7}$ so, too, the toad in Sicily, ${ }^{8}$ the gull, ${ }^{4}$ lizard, ${ }^{5}$ cuckoo, ${ }^{6}$ mole, magpie, and squirrel ${ }^{7}$ in Germany, the woodpecker ${ }^{8}$ in Scandinavia, and the peewit ${ }^{7}$ and owl ${ }^{10}$ in England.

(iv.) In the Faroe Isles the seals appear, like the wren in the Isle of Man, once a year in human form."

$\because$ In other cases the belief takes the form that animals can assume human shape. In Perthshire this was believed of cats, hares, and magpies. ${ }^{12 "}$.

In a third form of the belief, certain animals-the stork, for example-are men in other countries. ${ }^{13}$

\section{(c) The Animal as Life-index.}

(i.) Some animals, usually domestic or semi-domestic,

' Schulenburg, p. 157; Mullenhof, passim; MS. notes.

Arch. Rev., iii., 225.

- De Gubernatís, p. 629.

1 Müllenhof, p. 137 .

- Meier, p. 217.

- Grimm, Deutsche Sagen, pp. 515, 534, 571 ; Kuhn, Nordd. S., 289;.

Meier, 371, 372; for other refs. v. Wackernagel, iii., 237.

Meier, loc, cit.

- F., vi., 65 . F.L.J., vii., 57.

3o Hamlet, iv., 5.

"Grundtvig, Folkeviser, ii., $7^{6}$ n. ; ff. Antiquarsk $r$, loc. cit.

12 A. R., iii., 225.

"s Skattegraveren, viii., ril ; Kamp, Folkeminder, 221; Kristensen, Sagn, ii., 140 ; Stöber, Elsäss. Volksbü̈thlein (1859), i., 165 ; Evangile des quenouilles, p. 94 ; $f$. Aelian, De nat. anim., iii., 23. 
are regarded as being so intimately associated with the master or mistress that the lives of both come to an end simultaneously. The snake and the toad are very generally termed "Hausvater," \&c., and the death of the animal involves the death of the human being. ${ }^{2}$ He who kills a swallow kills his parents ${ }^{2}$ (Tirol), mother ${ }^{3}$ (Ruthenia), child (Niederlausitz). The dog is believed in Lancashire to die at the same moment as its owner ${ }^{5}$ so, too, the cat and cock in Switzerland, ${ }^{6}$ the black hen in Thuringia, ${ }^{7}$ and the black ox or cow elsewhere. ${ }^{8}$

In Brittany two crows are said to come and perch on the roof when the head of the family is dying; ${ }^{9}$ another account says that two crows are assigned to each farm and foretell the events in the family. ${ }^{10}$ They seem to be analogous to the house-snake of Germany.

\section{(d) The Animal as Genius.}

(i.) Connected with this belief is the Icelandic idea of the xttar-fylgia; this is a guardian spirit in animal form belonging to each family, and as such attached to the dwelling of the family."

(ii.) This leads us to the fylgia or personal guardian spirit, also conceived as an animal, which accompanies or precedes its owner on a journey in the form of a dog, raven, fly, \&c. ${ }^{12}$ In Norway the fylgia is believed to take the form

'Haltrich, zur V. der Siebenb. Sachsen, vii., 4; Rochholz, i., 146; Grohmann, No. 557; MS. Notes.

Wuttke, p. r3o.

Kaindl, p. IO4.

4 MS. note.

A. $R$., iii., 228.

- Rochholz, i., $16 r$.

- Witzschel, ii., 252.

- Grimm, Aberg., No. 887.

- Wolf, ii., 253; Ausland, 1846, p. 886.

10 Souvestre, Les derniers Bretons, i., I8I.

"Maurer, Isländ. Marchen, p. 85.

12 Maurer, Loc. cit.; $f f$. Cleasby \& Vigfusson's Dictionary. 


\section{Animal Superstitions and Totemism.}

of the animal most appropriate to the temper of the owner. ${ }^{3}$

(e) Animal Substitutes in Witchcraft.

We may further note those cases in which some part of an animal, usually the heart, is used to bewitch a person. Among the animals so used are the hare, frog, pigeon, and sheep. ${ }^{2}$ These practices must be clearly distinguished from those in which the bewitched animal is used to compel the presence of the witch. The analogy is with the use of a mannikin of paste or wax to represent the person who is to be bewitched.

\section{(f) Werwolves.}

I can do no more than mention in passing the belief in werwolves, which is allied to more than one of the supersti:tions detailed above.

The beliefs just detailed show close analogies with those of totem-tribes, and in certain cases can hardly be derived from anything but totemism of the individual form found in America.

I do not, of course, assert that these superstitions must be derived from totemism. I claim, however, that totemism explains them at least as well as any other theory. Looked at in the light of the facts to which I shall now call your attention, the totemic explanation is, I venture to say, by no means improbable.

Students of mythology and folklore have never been found wanting in ingenuity; and it will no doubt be possible in the present case also to suggest other explanations of the facts. But one theory always holds the field, provided it is not self-contradictory, until a better one is forthcoming. Wide-reaching explanations have, perhaps, their defects. But a preference in the opposite direction savours. of the spirit which explained the fossil shells in the Alps as

1 Meyer, p. '100.

' Hartland, Leg. Pers., ii., I05; MS. notes. 
relics of the pilgrims who crossed the mountains on their way to Rome. Mrs. Partington with her broom has never seemed to me quite an ideal figure.

\section{2. The Animal Tabooed or Sacrosanct.}

I now turn to the taboos. This section is highly important on its own account, but inasmuch as it exemplifies that local character of superstitions on which I have laid so much stress, it is not too much to say that it is the one on which more than any other the theory must stand or fall.

\section{(a) The Animal must not be Killed.}

To the list of animals which enjoy a local sanctity may be prefixed those which seem to be respected everywhere-the stork, robin, swallow, ladybird. They are, however, like many other animals on this list, either killed or carried in procession annually.

The following are respected locally:Bat: Baschurch (Salop). ${ }^{1}$

Bee: Russia, Normandy, Prague, and many other places. ${ }^{2}$ Beetle: Reutlingen (Swabia). ${ }^{3}$ Blackbird: Salop, Montgomeryshire. ${ }^{4}$

Butterfy, white', Llanidloes. ${ }^{5}$

coloured: W. Scotland. ${ }^{6}$

Cat: Zielensig (Mark), Berlin, Niederlausitz, $\uparrow$ Prague, Bavaria, parts of France, Thuringia, N.E. Scotland, \&c.? Cockchafer : parts of Germany. ${ }^{8}$

1 Burne, p. 214.

De Gubernatis, p. 507 n. ; De Nore, p. 270; Grohmann, No. 602.

MS. note.

- Burne, p. 214 ; MS. note.

- Mont. Coll., x., 260.

- Napier, p. Ir6.

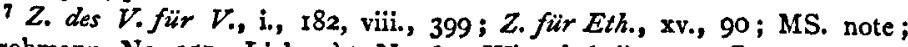
Grohmann, No. 357 ; Liebrecht, No. 64; Witzschel, ii., 277 ; Gregor, p. 123.

- Am Urdhsbr., Oct., 1882, p. 15. 
240 Animal Superstitions and Totemism.

Cockroach: Ruthenia, Lancashire.

Cormorant: Rerrick (Scotland). ${ }^{2}$

Cricket: Wales, Ireland, Ruthenia, Carinthia, France, \&c. ${ }^{3}$

Crossbill : Bohemia.4

Crow : Lechrain, Borgue (Scotland)..$^{5}$

Cuckoo: Hampshire, Connemara, Wales, Borgue, Finland, among the Slavs, and in Sweden. ${ }^{8}$

Dog: parts of France.?

Duck (Bergente): Sylt (?) ${ }^{8}$

Eel : Eibo. ${ }^{9}$

Frog: Ruthenia. ${ }^{10}$

Fly: Mecklenburg.'

Hare: Russia, Pennant Melangell. ${ }^{22}$

Lizard: Sicily, Pecek (Bohemia), Waldeck, Poland, S. Sporades, \&c. ${ }^{13}$

1 Kaindl, p. 105; Rolland, iii., 286. The presence of this insect, which only appeared in Europe a few centuries ago, in the list need not be regarded as a serious objection to the theory suggested. I. It is yery difficult to find out what the dialectical names do really mean; "Schabe" in S. Germany means a sort of louse. It is therefore possible that another insect is meant. 2. It is certain that in many cases transference of superstitions has taken place; the name "black beetle" shows that it has been universally classed among beetles; it has also taken over the superstitions of the beetle family. Cf. Raven, rook, crow, jackdaw.

2 Ethnog. R., No. 378.

- MS. nute; $F .$, v., I98; Kaindl, p. I05; Z. für d. Myth., iii., 29 ;

Liebrecht, No. I65, \&c.

- Grohmann, No. 524.

Leoprechting, p. 89 ; Ethnog. R., No. 399.

- F. L. J., i., 258, 394 ; 'F., ii., 246; Owen, p. 317 ; Ethinog. R., No. 394 ; Wander, ii., 1699; Arndt, Reise in Schweden, iii., 19.

Ijebrecht, No. 64 .

Mullenhof, p. T37-

- Globus, iv., 333 .

10 Globus, lxix., 73.

"Bartsch, Sagen, ii., I86.

". MS. note; Mont. Coll., xii., 56.

De Gubernatis, p. 634 ; Grohmann, No. 596; Curtze, p. 182; Am Urguell, iii., $272 ; \%$, x., 182. 
Magpie: Anglesey, $\uparrow W$. Ireland, N.E. Scotland, Sweden, E. Prussia, $†$ Tirol, Crossen (Mark), \&c.'

Mouse, white: Schönhirde (Bohemia). ${ }^{2}$

Owl: Mecklenburg. ${ }^{3}$

Ox, black : Germany. 4

Peewit: the Wotyaks. ${ }^{5}$

Pigeon: Moscow, $\uparrow$ Bohemia, Swabia. ${ }^{6}$

Quail : Münsterland.?

Redstart: Bohemia. ${ }^{8}$

Raven: Swabia, Lechrain, Sweden, Llansaintffraid (?) ${ }^{9}$.

Sea-swallow: Camargue, W. Ireland..$^{10}$

Snake: Tirol, $\uparrow$ Silesia, Ruthenia, Bohemia, \&c.; in Lübbenau the counts of Lynar respect the snakes in their park; they also have a snake as their crest."1

Spider: Sweden, Thuringia, Tirol, Silesia, Ruthenia, E. Prussia, $\nmid$ Niederlausitz, $\nmid$ Cornwall, Suffolk, $\& c^{12}$

.Swift: Hampshire, ${ }^{13}$

Toad: Sicily, Tirol, \&c. ${ }^{14}$

' MS. notes; F. L. R., iv., I07; F. L. J., ii., 258; Gregor, p. 138; Gaslander, p. 42 ; 2 . des $V$. fïr V., viii., 170; Kuhn, Nordd. S., p. 453 ; of. F., v. 283 .

Grohmann, No. 405.

'Jahrb. des V. für Mechl. Ges., ii., 123.

- Grimm, Aberglauben, No. 887.

- Globus, xl, 325.

- MS. note; Grohmann, No. 55I ; Meier, p. 217.

7 Strackerjan, i, 45.

- Grohmann, No. 509."

- Birlinger, i., 426; Leoprechting, p. 89 ; Gaslander, p. 48 ; Byegones, Sept., 1872 .

10 Rolland, ii., 387 ; F., L. J., iv., 253.

"MS. notes; Peter, Ji., 33 ; Kaindl, p. 103; Grohmann, No. I659; many other authorities might be ciled.

12 Wuttke, p. 130; Kaindl, p. r05; Gaslander, p. 43; MS. notes; F. L. R., v., 89; Suffolk F.; p. 7 ; Miss Marriage has given me the following Essex rhyme:-

"F. L. J., i., 394 .

"If you would live and thrive Let the spider go alive."

14 De Gubernatis, p. 629; 2. fur d. 'Myth., i., 7 ; Wuttke, p. 95 ; MS. notes.

VOI. $\mathbf{x l}$. 


\section{Animal Superstitions and Totemism.}

Wagtail: Wetterau, Languedoc. (I am not sure that the statement of Sloet in De dieren refers to a superstition. $)^{1}$

Weasel: Montagne noire, Ruthenia, among the Wends.'

Woodpecker: Sweden. ${ }^{3}$.

Wren: Ireland, Scotland, Wales, $\uparrow$ England, France. 4

Weevil : Esthonia. ${ }^{5}$

To the animals above mentioned may be added, on the testimony of Cæsar, the cock and goose in S. England. The seal in Ireland has already been mentioned.

We have therefore in all 47 animals which are or have been tabooed in various parts of Europe.

(b) The Animal may not be Eaten, Touched, or Used.

In this sub-section, complementary to the preceding, are found 18 of the animals on the above list. We have, in addition, the following for the first time :-

Stagbeetle: Ausbach. ${ }^{8}$

Lark : N.E. Scotland. ${ }^{9}$

Mole: Chemnitz.10

Wild duck: N.E. Scotland. ${ }^{21}$

Yellowhammer: Rhuddlan. ${ }^{12} \dagger$

Rook : N.E. Scotland.13

'Wuttke, p. 130; Rolland, ii., 228; Sloet, p. 221.

Nore, p. 98 ; Kaindl, p. I03; Schulenburg, p. 259.

- Gaslander, p. 48.

- Mair, Handbook of Proverbs, p. 52; Frazer, Colden Bough, ii., 142; MS. note ; Brand, iii., 194 .

- IIolzmayer, Osiliana, p. ro5 n. in Verp. der Esthn. Ges ez Dorpat, vol. vii.

- De Bello Gallico, v., I2.

- To these should perhaps be added the tit (Sloet, De dieren, p. 222).

- Grimm, No, 705 .

- Gregor, p. 139.

10 Grimm, No. 743.

" Gregor, p. 146.

12 MS. note.

is Gregor, p. $13^{6 .}$ 
Fish : parts of Ireland and Scotland.

Songbirds: Germany.2

Goose: Great Crosby. ${ }^{3}$

Wildfowl and poultry: S. England and Wales."

In these two sub-sections, then, I have shown that more than 50 birds and animals enjoy a local sanctity. ${ }^{5}$ This reveals the existence of local cults of extent hitherto unsus. pected, which embrace a large proportion of the commoner animals of Europe.

The animals in this section I distinguish as "taboo" animals."

Passing over the two remaining classes of taboos, I will now call your attention to-

\section{3.-Animals KePt in Captivity for Magical OR other SUPERstitious PURPOSES, OR FEd OR OTHER- Wise PetTed.}

Mr. Lang has argued that these cases have no evidential value. The schoolboy, he says, has guinea-pigs and mice, but they are not totems. ${ }^{6}$ But no one has ever suggested that the mice are kept in captivity for any other reason than that they afford their owner pleasure. The schoolboy does not keep pets because his father kept them before him. In folklore, on the other hand, the case is just reversed. Customs are kept up for no other reason than that they are customs. Mr. Lang's criticism neglects this important difference, and does not, therefore, bear upon the question at issue.

. The most important example in this section is a custom

i Elton, Origins of English History, p. I7o.

Wuttke, p. 130 .

A. R., iii., 232.

' $A$. R., iii., 233.

- To these may be anded the cases in which there is a superstitious aversion to using the feathers of certain birds in feather-beds. These birds are the hen, goose, pigeon, partridge, and sometimes wild birds generally.

- Folk.Lore, i., 12. 


\section{Animal Superstitions and Totemism.}

practised at Llanidloes." White butterflies are, as in the West of Scotland, ${ }^{2}$ fed on sugar and water. . Any doubt which might be felt as to the character of this practice is removed when we find that the coloured butterflies are killed as a part of the same custom. I cannot now discuss the interpretation of the latter part of the custom. I shall have occasion, however, to cite some facts subsequently which, perhaps, throw some light upon it.

In this case there is nothing to show the object of the ceremony. In Sicily, however, the toad is kept in captivity, ${ }^{3}$ like the mouse and the kingfisher ${ }^{*}$ in Bohemia, for the purpose of ensuring good luck. It is the custom in many parts of Germany to keep a crossbill in captivity ${ }^{5}$ it is believed to attract diseases. A kind of hawk is encouraged to nest on the houses in South Germany $;^{6}$ it is believed to protect the house. The peewit seems to have been kept for a similar purpose in the Middle Ages.?

Other birds are kept for purposes of divination, among them the pigeon, ${ }^{8}$ and in former days the wren and raven." The use of the hare by Boadicea is another example of the custom.

Domestic animals are also used for similar objects. I will here only quote one instance. The Lapps at the North Cape are said to consult . with a black cat, ${ }^{10}$ whom they regard as an ancestor, as to what it is advisable to do in cases of difficulty.

\section{4--Burying the Dead Animal.}

A practice which seems to bear clear marks of a totemistic origin is the burying of dead animals for other than

'Mont. Coll., x., 260. .

De Gubernatis, p. 629 .

2 Napier, p. II5.

4 Grohmann, 405, 443.

Jühling, 247, 249; Z. fïr d. Myth., i., 209; Heyl, 163, \&c.

- Mone's $A n z$, vii., 430.

'Mone, viii., 6r4; cf. Physiologus, Graff's Diatisca, iii., $3^{8 .}$

- Grohmann, 554.

10 Mone, Symb, u. Myth., i., 39.

- F. L.T. T., ii., 65. 
sanitary reasons. We have seen that the crossbill is believed to attract disease; in some parts it is believed to die in consequence; it must then be buried. ${ }^{1}$

I shall deal in a few minutes with the animals annually sacrificed; in certain cases they are, instead of being eaten, buried with considerable ceremony. In the Isle of Man the wren was formerly.interred in the churchyard. ${ }^{2}$ The cat is buried in Bohemia, 3 the sardine in Spain, the stockfish in Portugal, ${ }^{5}$ and the rabbit at Biddenham. ${ }^{6}$ Elsewhere the animal must be buried when it is found dead; this is done with the sacred fishes of Nant Peris. ${ }^{7}$

Although from lack of precise information I have not been able to include the mole among the arimals which may not be killed, there are grounds for believing that it was formerly respected in some parts. The present form of the belief is that a mole may be killed but must be immediately buried, sometimes not by the person who has killed it. ${ }^{8}$

\section{9.-Magical Powers Derived from the ANimal.}

To this important section I can allude only in passing. Powers of healing are ascribed to those who have eaten eagle's flesh, ${ }^{9}$ or in whose hand a mole or worm ${ }^{10}$ has died. In other cases the powers are believed to be acquired by touching the living animal, ${ }^{11}$ or by smearing some animal product on the hands. ${ }^{12}$

A highly important point in connection with these ceremonies is that they must be undergone at a certain age in some cases, and in others must be repeated annually.

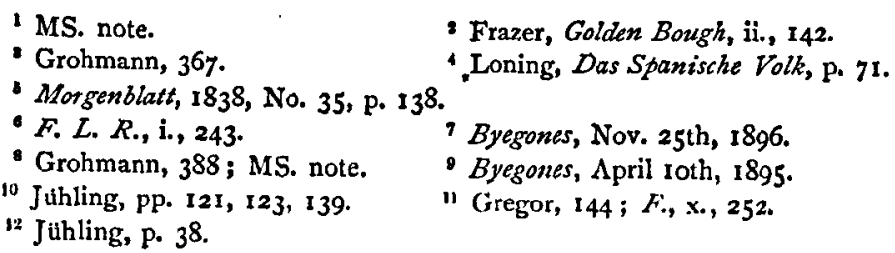




\section{Animal Superstitions and Totemism.}

It is tempting to see in the former a survival of initiation ceremonies, and to connect the latter with other annual ceremonies of which $I$ shall have more to say in a few moments.

"The importance of these customs leads me to treat them separately from the use of the animal in magic, from which they do not differ essentially,

Closely connected with the magical powers of the animal, dead or alive, is its ability to foresee and foretell the future.

\section{II.-Animals used In Augury and Magic.}

Into the questions raised by superstitions as to (1) omens and (2) magic I cannot enter at length. I will do no more than call attention to the main points to be considered.

I. (a) "Taboo" animals give both favourable and unfavourable omens; their appearance is frequently believed to presage a death.

(b) "Lucky" animals" give both good and bad omens; their appearance is frequently believed to presage a death.

(c) Popular language makes the animal itself the cause of the event foretold: it "bringt Glück," "porte bonheur," \&c. The ill-luck may be averted by killing the animal.

2. (a) As I shall show later," "taboo" animals, sacrificed once a year, are powerful in magic.

(b) Unlucky, no less than lucky, animals are employed in magic.

We may conjecture that all "taboo" animals used in magic were originally sacrificed annually. But if the magical powers of the animal were a result of its sanctity,

"By "lucky" animals I mean those whose presence (not apparition) is considered lucky. 
the remaining animals used in magic were probably "taboo" animals.

"Lucky" animals are taboo. But "taboo" animals are not always lucky. We have other instances in which sacred animals have in course of time become separated into two classes-holy and unclean animals. We may conjecture that the "lucky" and "unlucky" animals are the result of a similar process. They were originally all taboo. Mutatis mutandis this is also true of the ominous animals.

The facts are difficult to explain on the assumption that we must look for their origin to more than one suurce.

Admitting that in later times other causes have played their part, it seems clear that we must derive the great mass of the usages under consideration from a period when animals were sacred, and, as the facts which I shall now bring to your notice seem to suggest, solemnly sacrificed once a year.

\section{III.-Annual Ceremonies.}

I. SACRIFICE.-In the two great totem-areas of Australia and North America sacrifice is either unknown or unimportant. Australia has no domestic animals; America had only the dog, and the dog was the only animal commonly sacrificed. ${ }^{1}$

It is possible, therefore, that a connection exists between sacrifice and domestication (i.e. for many peoples between sacrifice and civilization), rather than, as Professor Jevons maintains, between taboo and domestication. ${ }^{2}$ We find traces, in European customs, of a custom of retaining the victim in captivity for a period before the sacrifice. We may conjecture that this practice would be suggested by considerations of convenience in comparatively early times;

1Relations des Jes., 1667, p. 12; Perrot, passim; Morgan, League of the Iroquois, p. 207, \&c.

2 I find Dr. Hahn has made the same suggestion, to explain the domesti. cation of a single animal, in Demeter u. Baubo, p. 28. 


\section{Animal. Superstitions and Totemism.}

possibly the desire to have the totem at hand for guidance by means of omens and for protection contributed its share to the development of the custom, which, once established, would readily grow into one of keeping the sacred animals in captivity in greater or smaller numbers without any definite intention of sacrificing them, i.e. merely as sacred animals, like the geese in the Capitol or the droves of sacred horses in Germany.

In this position the animals would gradually accustom themselves to the company of man, i.e. they would become tame. A further step was taken when man, instead of eating the sacred animal itself, began to use its products as a means of effecting communion with the tribal god. The animals were in this way gradually accustomed to yield, for the use of man, the milk (and other products) which they in a wild state produce for the benefit of their young.

Sacrifices were originally annual; later they were performed more frequently, originally, perhaps, from a desire to secure the presence and assistance of the god, afterwards from a growing appreciation of the merits of roast pig and other delicacies.

- In the case of the uneatable or less tasty animals, this motive was. naturally weak or entirely absent; these they were content to sacrifice as before, once a year. In the case of the other animals also there was, however, perhaps a tendency for the original yearly sacrifice to retain a greater importance than those subsequently engrafted on it.

The sacrifice was performed by members of the clan; the institution of priesthood was. unknown; none but members of the clan might take part in the sacramental meal. The clan was not, however, confined to a given area; this meal would, therefore, be celebrated wherever members of the clan were residing This type we may term "clan. sacrifice." 
The totem-clan, however, tended to develop; it expanded into a larger group. This explains the position of certain animals like the great hare of the Algonquin tribes. In other cases the totem-tribe tended to pass into a local group. This resulted in the sacred animal of the clan becoming the sacred animal of the local group; its worship was confined to a certain area. This type may be distinguished as " tribal sacrifice."

We find, as I shall endeavour to show, examples of both types in Europe at the present day. These survivals I arrange in three groups, which may be termed the "Hunt," the "Hahnenschlag," and the "simple" classes.

Most of these sacrifices present one or more of the following features :-

(1) There is no priest or other person specially selected for the task of slaying the victim; the slayer of the animal is, however, frequently the recipient of special honours and a title which he bears for a year.' (2) The ceremony is performed once a year, usually on a specified day; the animal is occasionally selected some time before the actual sacrifice. (3) The use of iron is frequently tabooed, and the animal may not be shorn. (4) The head of the animal is frequently struck off and is specially sacred.2 (5) The sacrifice is preceded or followed by a procession, in which the sacred animal is paraded round the village or town.

I Handelmann, p. 25; Mannhardt, Korndämonen, I6; Peter, ii., 278 ; Nore, p. 20 ; Globus, vii., 304 ; De Gubernatis, 475 n.; Rolland, vi., 104, 175 ; Sébillot, Coutumes pop. de la H. B., 25I; Meyrac, Traditions des Ardennes, pp. 66, 67 n., $c f$. p. 61; Reinsberg-Düringsfeld, Cal. belge, 131, 341, \&c. We find a king in the egg-games and at cock-fights; Sebillot, Meyrac, loc. cit. For an interesting and important parallel to the customs in this section v. Globus, xvii., 24 .

2 There is an obvious connection between this custom and that of fixing carved or real heads round the fields, on the houses, \&c. Perhaps the explana. tion is that the head was regarded as the residence of the soul. In West Prussia a method of preventing a dead member of a family from inflicting disease on the living is to open the coffin and cut off the head. Globus, xix., 96. It is further a well-known prehistoric burial custom. 
(6) The animal is commonly either dismembered and distributed, or eaten at a common meal. (7) There are traces of the common meal being confined to the kin in some cases, in others to the inhabitants of the locality. (8) In some cases cakes in the form of, or bearing the name of, the animal, are substituted for the animal itself.

I will now deal briefly. with the three forms of sacrifice,

\section{(a) The Hunt.}

We have already seen that the wren is a taboo-animal in the west of Europe. There is, however, a widespread custom, discussed at length by Dr. Frazer in the Golden Bough, of hunting it annually; this hunt was commonly at Christmastide or New Year, but is also found at other periods of the year. ${ }^{3}$ The wren was usually killed in the process; it was then carried round to all the houses, a feather being in some cases left at. each house; to this feather were attributed magical properties. In other cases the bird was carried round alive. In Wales there are traces of a custom of roasting, $i . e$. eating the wren. In the Isle of Man the featherless body was buried.

Other customs of this type are the following :Bull : Stamford. ${ }^{2}$

Cock: Guben, Belgium. ${ }^{8}$

Deer: Oxfordshire at Whitsuntide, Epping Forest at Easter, Ireland St. Martin's Day.*

Hare: Leicester; Coleshill, Caistor, and elsewhere in South England at Easter, Llanfechain in October, Ireland on St. Martin's Day. ${ }^{6}$

- Golden Bough, ii., 14t ff; Byegones, Sept., 1872, April 22, 1885; Notes and Queries, 4th S., ix., 25; Suffilk Folklore, 125 Bthnog. S., No. 599.

* Hone, s482; of. F., vii., 385 .

- MS. note; Reinsberg-Duaringsfeld, 200.

I F, viii., 310; Hone, ii., 460; F. $L, R_{n}$, iq., 108, of y., 166.

- F., iii., 442; Sussent Daily Newer, June 10, 1895 i Mont. Coll., xvii., II8; F. L. R., iv., 108 . 
Pig: Würzburg at Martinstide, (probably a pig-baiting is $\therefore$ meant).

Owl; in Suffolk at Christmas.?

Ram: Eton and East Wrotham. ${ }^{8}$

Squirrel: Wales, Suffolk at Christmas; Cammin (Pomerania) and Harz Mountains at Easter; Lelbach (Waldeck) at Ascensiontide; Easling on Nov. 3oth; the Wotyaks, Oct. ist."

We may perhaps add the fox, which was one of the animals hunted in Ireland on St. Martin's Day. ${ }^{\mathrm{s}}$

\section{(b) The Hahnenschlag.}

This type I name after the custom which is in modern folklore the commonest and best preserved of the many variants-that of striking blindfold at a cock.

There are, however, sometransitional forms which must first be dealt with. In Whitsun-week a lamb was formerly provided at Kidlington (Oxfordshire), after which the girls of the township ran with their thumbs tied and tried to catch the animal with their mouths; the successful one was proclaimed Lady of the Lamb, which was carried before her to the green. The next day the lamb was eaten at a feast at which the lady presided. ${ }^{\circ}$

A variant of this custom is the catching the greasy pig,

1 Z. für d: Myith., i., 107.

2 Brand, i., 268; on Valentine's day in the West of England three single young men had to go out and catch an owl and two sparrows, which they carried round the village; Hone, $i_{1}, 227$.

- Brand, ii., 314.

- Owen, p: 351 ; Brand, i., 268; Wolf, i., 78; Kuhn, Nordd. S., p. 374 ; if. Liebrecht, zür $V_{0}, 26 \mathrm{I}$; Curtze, p. 441; Hone, i., 1539; Buck, Die Wotjaken, p. 162. Mr. Hartland informs me that it used to be hunted at Dursley on May-morning.

- F. L. R., iv., 108. Miss Marriage informs me that one of the palace courts at Dresden was used for fox-hunting. of. Preller, Roman Myth.,? p. 436. The gulls were hunted on the Schlei on July $23^{\text {rd }}$ (Schutze, Idiotzkon, iii., 97.)

- $F$., viii., 315 . 


\section{Animal Superstitions and Totemism.}

found : in Schleswig-Holstein and Hungerford ${ }^{2}$ a pig shorn and greased had to be caught by the tail. In Belgium the eel had to be similarly caught. ${ }^{2}$ Climbing the greasy pole is another form of the same custom. ${ }^{3}$

In Spain and Germany it was the practice in the Middle Ages to let loose a pig in an enclosure; it was then pursued by blindfolded men with sticks."

We have thus a series of transitions leading from the hunt to the Hahnenschlag. In the many variants of the latter custom we may distinguish four main forms.

(i.) The cock is (a) buried in the earth up to the neck, $(\beta)$ covered with a pot, $(\gamma)$ carried on a man's shoulders, $\& c$., and struck at or beaten by persons with their eyes blindfolded. 5

(ii.) The cock is hung up in a pot or from a line and thrown at with sticks; in other cases the competitors ride underneath and endeavour to seize the bird; elsewhere it is shot at. ${ }^{6}$

(iii.) The cock is solemnly condemned to death; its forgiveness is begged, and its head struck off with a wooden sword, if possible at one stroke. The people are sometimes sprinkled with the blood.7

(iv.) The possession of the cock is decided by athletic competitions or by chance. ${ }^{8}$

Variants of these customs are found in all the south-

1 Handelmann, Spiele, p. 23 ; Hone, ii., 140 .

Breton, Belgique, i., 241 .

- Brand, ii., 303. For other popular amusements possibly referable tó a similar source, see Hone, i., 573, ii., 1401 ; Schütze, rdiotikon, iii., 7.

- Raumer, Gesch. der Hohenstaufen, vi., 590.

- Owen, Old Stone Crosses, p. I91; Am Urquell, I, 129 ; M. C., iv., 135, x., 264. Greek coins often represent animals on men's shoulders (Frazer Pausanias, v., 87). Does this point to a similar custom ?

- Mont. Coll., iii., 86; Schuster, Deutsche Myth. aus sieben-sächs. Quellen, p. 268.

' Vernaleken, Mythen u. Bräuche, 303, 305 ;' Reinsberg-Düringsfeld, Fest-kal., p. 52; Coremans, 83, 103; Pfannensch mid, 299.

- Pfannenschmid, p. 559; Zeits. fïr die el Welt, I801, 445; Reimann, Deutsche Volksferte, p. 13. 
ern and western portions of Europe and in Spanish America. ${ }^{1}$

Other animals sacrificed in the same way are-

Bear: Swabia (iii.). ${ }^{2}$

Frog: Bohemia 3 in the ceremonies connected with the King of the May (iii.).

Goat: Jüterbock (ii.) ${ }^{4}$

Goose: Bavaria, Brittany, Saxony, Switzerland, Derbyshire. ${ }^{5}$

Pigeon: very frequently in the Middle Ages; later a wooden bird was shot at ; this custom is still found in Schleswig-Holstein (i.) (ii.). ${ }^{6}$

Cat: Pomerania (combined with a hunt), Kelso, Shropshire, \&c. (ii.) ${ }^{7}$ the cat was frequently shut up in a wooden bottle with a quantity of soot, and he who beat out the bottom and escaped the soot was the hero of the day. ${ }^{8}$ Owl: North Walsham. ${ }^{9}$

Deer: to this class belongs the running deer in the Schützenfest of Burg. ${ }^{10}$

- Cockfighting seems to be a variant of this custom; it was practised on Shrove Tuesday, the same day as the Hahnenschlag. I hope to deal elsewhere with the "Brauthahn," some forms of which include the "Hahnenschlag." The egg-games may also be mentioned here; v. Rolland, vi., 105 ; Henderson, p. 84; Sebillot, Coutumes, p. 251 ; F. L. J., iv., 131, vi., 60; Nicholson, p. 12 .

2 De Gubernatis, p. 426.

- Mannhardt, $B k$., p. 354 .

- Kloster, xii., 76 .

- Kloster, xii., I005; Rolland, vi., I75; Meyrac, p. 95; Grabner, Ver. Niederlande, p. 360 ; for other refs. v. Jahn, Opfergebrázeche, p. 234.

- Am Urquell, i., I29; Jahn, p. I49; Handelmann, p. 12.

Jahn, p. IO7; Brand, ii., 303; Grabner, p. 36I; Burne, p. 450; Handelmann, p. 22.

Shakespeare, Much Ado About Nothing, i., 2 ; Kloster, xii., 552. The innsign of the "Cock and Bottle" is obviously an allusion to this, as is that of the "Dog and Duck" to a similar amusement. "Gare au pot au noir" is a phrase used in France in playing Blind Man's Buff.

- De Gubernatis, p. 560. According to Hone this was only a practical joke. It ' will, however, appear later that the custom probably existed in Germany. At Lille ducks and rabbits were used (Desrousseaux, i., 289).

to Inndelmann, p. 25. Did the Elaphebolia take its name from a similar practice? 


\section{Animal Superstitions and Totemism.}

Sheep : Elsass; S. and C. Germany ${ }^{1}$ (ii.) (iv.).

Stagbeetle: In Lautenthal the boys, when they found a stagbeetle in springtime, buried it and struck at it with eyes blindfolded. The winner was accompanied home by his companions.?

Glowworm: A similar custom seems to exist in Italy with regard to the glowworm, which is threatened with a : beating just as the snail is in England, in the wellknown rhyme.s

- To these must be added the blackbird, sparrow, yellowhammer, toad, and perhaps the herring? and dog.

(c) The Simple Form.

(i.) The first butterfly is killed in Cornwall "in order that they may conquer their enemies." 7 Similar customs are found in France, Somerset, Devon, and North. Hants ${ }^{8}$ the first snake in W. Sussex, the first wasp in parts of England, the first toad at Berne. ${ }^{9}$ In Schleswig-Holstein the first bee should be killed and put in the purse in order to have money all the year. ${ }^{10}$ With this may be compared the well-known cuckoo custom; futther, that of running, rolling on the ground, \&c., on seeing the first swallow, wagtail, \&c., in order to be free from disease. ${ }^{11}$

I For refs. v. Jahn, p. igo.

Kuhn, Nordd. Geb., p. 377 ; sf. N. so., and Ser., ii., 83,

De Gubernatis, p. 504; $F$. L. J., v., 193 .

- F. L. J., ii., 120; Napier, p. I12; Rolland, iii., $49 ; N . \&$ Q., 3rd Ser., iv., 492 .

- Rolland, $3 i$., 126.

- Nicholson, p. 22. Bartsch, Abergl. aus Mecklenbutrg, ii., 139.

TF. L.J., v., 214.

- Sébillot, Coutuntes, p. 365 ; Rolland, iii., 315 ; Hone, Table-book, p. 339. Miss Marriage informs me that in Essex the head of the first white butterfy is bitten off.

- F. L: R., i., 8; Rolland, iii., 54, 272. In Pomerania the head of the first cockchafer should be bitten off as a protection against fever. Juhling, p. 94. 10 MS. note.

n Grimm, Na. 217, 348, 986; Z. fïr d. Myth., ji., 95 ; Leicester Folklore,

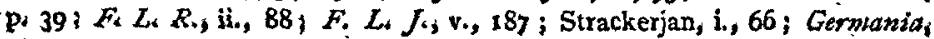
xix., 3491 of. Panzer; ii, 125, zo3; Aristophanes, Aves, 498; Pliny, Hist. Nat., R*X,1 25. 
(iia.) In Linda (Saxony) a crow shot on March ist and hung up in the cowhouse was believed to protect the animals against witcheraft. The glowworm taken on June 24th brings luck in Belgium. ${ }^{3}$

.. $(\beta)$ Elsewhere a period is fixed for the killing of the animal instead of a single day. In the Tirol the young raven must be taken in March for use in medicine.? The toad is killed in the Tirol in the weeks from July 15th to August I 5 th, and hung in the stable. In Lechrain it is first transfixed and then hung in the stable. ${ }^{3}$ In Mecklenburg the weasel killed between August 15th and September 8th is specially powerful in magic. ${ }^{4}$ In Oldenburg the magpie shot in March protects against flies. ${ }^{5}$ The March hare is specially powerful in magic. ${ }^{6}$ In other cases the animal has to be killed before a certain date. At Herda a crow or magpie shot before March is nailed in the stable. ${ }^{7}$ In Hungary snakes and marmots should be caught before St. George's Day (April 23rd) for use in magic. ${ }^{8}$

(y) Elsewhere the custom takes the form of killing the animal at all seasons. It is important to notice that this custom exists in the Isle of Man side by side with the annual hunt. ' In Brandenburg and France the toad is transfixed and stuck on the dunghill.10 In Wicklow and Tipperary the weasel is hunted down. ${ }^{11}$ In N.E. Scotland

' Dähnhardt, Volkstümliches aus den $K$. Sachsen, i., 79; Rolland, iii., 343 . So too the ladybird (June 25th). Rolland, iii., 368. The hare (March Ist). Juhling, pp. 55, 56, 58 .

2 Heyl, p. r52.

- Wuttke, p. 95 ; Leoprechting, p. 83.

- Schiller, ii., 10.

- Strackerjan, p. 67.

- Juhling, p. 57.

7 Witzschel, ii., I96.

- Jones and Kropf, Folktales of the Magyars, xlix., 1. Similarly the lizard, butterfly, bat, frog, hare, deer, hedgehog, toad, mole, nagpie, weasel, wolf. Jones and Kropf, loc. cit.; Jühling, passim.

- Denham Tracts, i., 203.

$10 Z$. des V. für V., i., 182; Rolland, iii., 49.

" $F$., iv., 36 r. 
256 Animal Superstitions and Totemism.

and Bohemia the 'yellowhammer is killed, in Shropshire the bat, ${ }^{2}$ in Pitsligo the small tortoiseshell, ${ }^{3}$ in Normandy the salamander, 4 in Llanidloes and Northumberland coloured butterflies, ${ }^{6}$ in the Pays rouchi tits. ${ }^{6}$ There is, however, a possibility that this custom points to a belief that these animals are permanently hostile, a view which also seems to manifest itself in the belief that certain animals by their mere presence (not appearance) bring misfortune. Into this question, however, I cannot now enter.

$(\delta)$ In some cases an animal is killed annually without being subsequently used in magic. At Erfurt the magpie is killed on Good Friday, at Bingen the badger at the festival of St. Roschus. ${ }^{8}$ The robin at Le Charme at Candlemas. ${ }^{2}$ Snakes and toads at Ortenau. ${ }^{10}$

(d) The Torture Form.

It is possible that we should include the baiting of bulls, badgers, bears, cats, ducks, and other animals under the head of sacrifice."

At Venice in the Middle Ages the head of the bull had, as in the Hahnenschlag, to be struck off at one blow. Bullbaiting was practised in Ireland on St. Stephen's day, an important day for sacrifices, as we have already seen..$^{12}$

(e) The Precipice Form.

An interesting form of sacrifice, recalling the eastern

'Gregor, 139; Grohmann, No. 518.

- Burne, p. 214.

TF. L. R., vii., 43 .

- Rolland, iii., 79.

- Mont. Coll., X., 260; Denham Tracts, ii., 325.

- Rolland, ii.s 305.

7 Witzschel, ii., 196.

- Reimann, p. 437.

- Rolland, ii., 264.

to Meyer, p. 94.

"Schutze, ii., 141, scci; of. Jahn, p. 230; Körber, Volksbelustigungen, p. 15.

"Vulpius, Curiositäten, ii., 25; F. L. J., vi., 54, 62. 
parallels, and others cited by Robertson Smith, is that of throwing the animal down from a church tower or other edifice. The animals so killed were:-Cat: Ypern (Belgium), Attendorf (Mark). ${ }^{1}$ Goat: among the Wends on July 25 ; at Liepa Kirmess. ${ }^{2}$ The goat was also sacrificed by the Esthonians with singular ceremonies on St. Thomas's day at Allentaschen.s

\section{(f) The Fire Form.}

The cat, fox, snake, squirrel and others were burnt in the Easter or Midsummer fires. ${ }^{4}$ Mannhardt identifies these with the spirit of vegetation. The connection with these fires is, however, the only ground for this identification, and these same animals are killed at the same season in ceremonies quite unconnected with vegetation, as we have already seen. It is less probable that an integral part of a custom should be detached than that a ceremony practised at the same season should in some cases be incorporated. ${ }^{5}$

\section{IA.-PROCESSION.}

Mannhardt also identifies animals carried in procession at Christmas and other seasons of the year with the corn or tree-spirit. But in many cases the grounds for this are very slight; and there is no ground for connecting the majorities of the animals led in procession with either form of the vegetation cult, but it is far more probable that a custom should acquire an agricultural tinge in some few cases than that it should in the majority of instances lose all traces of its original meaning. We may even go further and argue that the animal corn-spirit is in every case an

' Coremans; p. 53 ; Z. far d. M., ii., 93.

Sommer, Sagen aus Thüringen, p. 179; Mitt. des Nordböhm ExcursionsClubs, xxiii., 108.

- Possart, Die russischen Ostseeprovinzen, ii, 172.

- Mannhardt, passini.

- To put the matter in a concrete form, I find six cases in which the squirrel was hunted; in only one or two at most was it burnt in the Easter fire. I conclude that the squirrel hunt was originally independent of the fire, into which animals were thrown but seldom.

VoL XI. 


\section{Animal Superstitions and Totemism.}

example of this "superposition." The casual theory defended by Dr. Frazer seems untenable." The identification of the chance animal in the corn with the cornspirit could hardly have led to the permanent recognition of one animal as such in a given district. Further we do not know that the chance animal ever was so recognised (as the chance stranger was); we cannot therefore argue, as Dr. Frazer does, that the two cases cannot be dissociated in any attempt at explanation; it is Dr. 'Frazer's own hypothesis that the cases are parallel, and he quotes no facts in support of it. On the other hand it is simple and satisfactory to see in animal corn-spirit the sacred animal of a district identified with the corn-spirit because it was sacred in the pre-agricultural days. This view is favoured by the fact that a large number of animals which are in some cases comparatively rare are regarded as embodying the corn-spirit; I shall have occasion to call attention in another connection to facts connected with the harvest supper which support this hypothesis.

- Analogy suggests that the animals carried in procession ${ }^{2}$ were originally sacrificed, and there are facts which tend to prove that the Christmas horses and other animals were actually at one period killed and eaten.

Before leaving the question of sacrifice I must direct your attention to the great importanice of the period about the winter solstice for ceremonies of this nature. The importance of this point will be seen later.

III. 2. - Cómmunion with the Sacred Animal.

This was effected $(a)$ by the distribution of its feathers, skin, $G^{-} c .,(b)$ by eating it.

(b) i. Among the animals thus eaten are: cock, ${ }^{3}$

I Golden Bough, ii. 33.

- Bear, boar, cockchafer, cow, crow, cuckoo, donkey, eagle, fly, fox, goat, horse, magpie, ox, rabbit, sardine, stockfish, sheep, stork, swallow, and wolf. To these may be added the cricket, sold in Florence on Ascension Day. Animals that appear in the other lists are not mentioned again here.

$\checkmark$, the refs. on p. 252 . 
deer, ${ }^{1}$ goat, ${ }^{2}$ goose, ${ }^{3}$ hare, ${ }^{4}$ pig, ${ }^{6}$ ox, ${ }^{6}$ sheep, ${ }^{7}$ shellfish and mussels. $^{8}$ By including the animals eaten at particular seasons, such as the carp at Christmastide in SchleswigHolstein, the list might be considerably extended; the swan would naturally be included with others less important. At All Souls', Oxford, the mallard was eaten on January $14^{.}$ It may also be noted that where it is forbidden to eat an animal or bird not commonly used for food, such as the , woodpecker, ${ }^{10}$ there is a strong probability that it was formerly eaten ritually.

In this connection I may also call attention to the Painswick dog-pie..1 It can, I think, hardly be doubted that the $\mathrm{dog}$ was originally eaten there. It is a priori highly probable that the feast-customs of our villages go back to an extremely early date. Moreover, we find other instances of the same sort. In a Cornish village blackbird-pie is eaten on Twelfth-day. ${ }^{12}$ Stories are told in Lincolnshire and France ${ }^{13}$ of flies or cockchafers being eaten at the feast, and we may conjecture that there is a substratum of

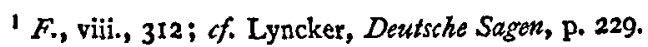

Mitt. des n.b. Ex-cl., loc. cit.

- At Martinmas, v. Pfannenschmid, pp. 228,'504, \&c. ; at Michaelmas, Birlinger, i1., 163; Jahn, p. 233; of. Owen, p. 351; Arch. Camb., 1853, p. 325: Hone, i., I645; F. L. J., iv., I11.

- Elton, Origins of E. History, p. 391 n.; F., iii, 444 .

- Am Urquell, ii., 48; Pfannenschmid, p. 204; Meyer, p. 103; Jahn, pp. 103, 229, 265.

- Jahn, p. 100; Kuhn, Märkische Sagen, p. 368 ; Schiller, ii., 5 .

- Bavaria, I., i., 372 ; Z. des V. für V., v., 205, ff; Pfannenschmid, pp. 292, $559 ; F$. ì., 2 I $f$.

F. L. J., iv., 36r ; Courtney, Cornish Feasts, pp. 8. 21, 25. To the list of animals eaten we may perhaps add the wren, robin, and cat, which are roasted or boiled. Byegones, April 22nd, 1885 ; Rolland, ii., 264; Grohmann, n. 367. The name "Eselsfresser" applied to Silesians in Germany, points to a similar custom. . Sinapius (Oelnographia, i., 342-3) tells us that Silesia was said to have so few vineyards because they ate the ass of Silenus I

- Hone, Table-book, 44 .

${ }^{10}$ Kaindl, ro4.

" $F$., viii., 391.

12 Courtney, p. 8 ; $c f$. Hone, Table-book, p. 667.

13 $r .$, viii., 365 . 


\section{Animal Superstitions and Totemism.}

fact. At Towednack (Cornwall) the feast is termed "the cuckoo's feast," and this points to a similar usage."

This evidence of the ritual eating of animals not commonly used for food is in itself highly important; still more important, however, is the local character of the customs, of which we also find traces in the Oxfordshire deereasts.

More important even than these local customs are the ceremonies in which the kin alone may take part. The Karelians, like the Esthonians of Oesel, 'kill a lamb on July 29th; it has never been shorn, and may not be killed with a knife; its blood is sprinkled over the threshold. No stranger may eat of its flesh. ${ }^{2}$ The Easter lamb is killed in Greece by a male member of the family, roughly cooked on the street, and often torn to pieces without a knife. It is eaten by the family. ${ }^{3}$ The Lithuanians killed a cock and hen at their harvest festival without shedding their blood; they were prepared and eaten in, the absence of the servants. In Lippe the harvest cock was eaten by the farmer, his family, and next of kin; the servants and labourers had none of $i t^{s}$

I need hardly point out that these customs cannot be derived from the ordinary practices; the latter, on the other hand, may easily have originated in the ritual feasts of the kin.

(ii.) In certain cases we find cakes in animal form; these have clearly taken the place of the animals themselves. I will merely remark that the material of the cakes does not

'F. L. J., v., 224. For other cuckoo-customs of. Harou, p. 33 ; Reinsberg, Durings feld, ii., 115 . Does the gaine of Ilide and Seek point to a custom of hunting the cuckoo? $C f$. Wander, ii., r699.

3 Mannhardt, $A . W . F$. p. $160, n$.

- F., i., 275 ; Das Kloster, vii., 915.

- Mannhardt, quot. Praetoris, Deliciae Prussicae, v., 7, 23.

- Pfannenschmid, iii., 422: 


\section{Animal Superstitions and Totemism.'26}

warrant us in connecting the practice with agricultural customs. ${ }^{1}$

The customs dealt with in this division have been, so far as their distribution is a criterion, of the type I term "clan" ; locality has, however, frequently replaced kinship. I now turn to evidence which seems to point to "tribal" sacrifice of the same archaic type.

\section{GaMes of SaCRifice.}

The primitive sacrifice dealt with in the last division has survived in more than one other form. Time will not permit me to deal with more than one of these, and that very briefly, merely indicating the conclusions to which I have come.

The most important example is the game of blind man's buff, which corresponds in form to the Hahnenschlag.

The game is known nearly all over Europe by names derived from animals, as the following list will show :

Blind cow : N. and C. Germany.

- mouse: Faroe Isles, part of Denmark, S. Germany Illyria, Servia, Croatia.

- he-goat: part of Denmark, Pomerania, Finland, Esthonia, England, Scandinavia.

she-goat: Portugal.

- hen: Spain, Wales.

- cat: part of Italy, Bavaria.

- fly: part of Italy. .

- owl: Altmark.

- wolf : Samland. ${ }^{2}$

i Animal cakes are found in the following forms:' bear, boar, cock, cockchafer, deer, dog, goat, hare, horse, lark, pig, rat, sheep, snail, wolf. Clay donkeys were sold at Erfurt fair. The "Brauthahn" and Easter lamb are similarly made in butter (Fromm, Pp. 108, 123; Bavaria ii., 2, 381).

${ }^{2}$ Handelmann, pp. 33, 69-73, Iog-III ; Grimm, Wörterbuch, s. v. Blind; Archivio per la Trad., viii., 43I ; Biblioteca delle Tradizioni pop., xiii., I93; Gomme, Trad. Games; Kor. blatt. fiur n. d. Spr. forschung, vii,, 90 ; /finde, Slownik Jesyka Polskiego; MS. notes. In the French name, Colin seems to be a form of Nicolas (Dẹsrousseaux, Moeurs, i., 289). 
In ancient Greece it was known as the brazen $f_{1} i^{1}$ in Iceland as the fox-game; ${ }^{2}$ in Lithuania hare-catching is a similar game. ${ }^{3}$

The explanation of these names is that the players originally wore masks; the game is known in some cases as the "blinde Mumm,"4 or blind mask. This is, perhaps, why in the Hahnenschlag the person who tries to kill the cock is frequently blindfolded; this custom points to a practice of wearing masks at the sacrifice. The player who is "it" seems to be the sacrificer; he bears the same name as the victim, just as in agricultural customs the reaper of the last corn bears the same name as the last sheaf.

Blind man's buff is essentially a Christmas game; we have already seen that the sacrifices of the winter solstice are highly important; the distribution and wide popularity of blind man's buff bear further testimony to this. We may infer that the Christmas mummers originally officiated at a sacrifice at this season. We know from Strutt and other authorities that the mummers frequently wore animal masks. We may further conjecture that the animals paraded at this season of the year were not tree or corn-spirits appearing after their winter sleep was over; they were simply victims, like the wren and the squirrel. The custom of going dressed in skins of animals at this season, alluded to in the Penitentials of Theodore, ${ }^{6}$ is another form of the custom of wearing animal-masks. Klaus and other figures appearing at or near Christmas were possibly also connected with sacrifices: Klaus, unlike other personages who lead animals

1 Pollux, Onomastikon, ix., 123, ff. 113.

${ }^{2}$ Cleasby and Vigfusson, Dictionary, s. v. Skolla.

- cilobus, lxxiii., 320.

- Handelmann, p. 7I; of. Strutt, Sports and Pastimes.

- Frazer, Golden Bough, passim. On the other hand, it may be that the whole body of sacrificers wore masks and bore the name of the animal; $c f$. Frazer, Pausanias, iv., 223; Davies, Mythology of the British Druid, p. 4J4.

' Si quis in Kal. Januar.' in cervulo vel vitula vadit, \&c. 
round and collect money, is the proverbial bringer of gifts; he also carries a rod, identified by Mannhardt as the "Lebensrute."1

The two characteristics of Klaus noted above he shares with the "Hudler." In the Austrian custom known as "Hudlerlaufen" a man disguised in a mouse-mask pursued people with a whip; when he had caught them he treated them at the inn and then set out in search of others. ${ }^{2}$ This custom I interpret as a survival of human sacrifice which had taken the place of a mouse-sacrifice. It can hardly be a mere coincidence that the "Hudler" wears a mouse-mask in a part of Europe where blind man's buff is known as "Blinde Maus."

We have seen that the "Hudler" gives food to those whom he catches; we find a corresponding feature in blind man's buff; in Germany, Sweden, and probably other parts of Europe reference is made in the game to eating meal and milk, ${ }^{8}$ obviously the sacred food which, as in the Boupóvia at Athens, ${ }^{4}$ the victim had to eat. To the whip or rod carried by Klaus and the Hudler corresponds the wand used in some forms of blind man's buff. ${ }^{5}$ It has another parallel in the whip carried by the priest in the Indian village rites described by $\mathrm{Mr}$. Gomme in his Ethnology in Folklore. The object was, perhaps, to make the victim move or shiver, a result usually attained by pouring water on it. ${ }^{8}$

The eating of meal and milk is also alluded to in the

1 Baumkultus, passim. Klaus= Nicholas, and the French name for Blind Man's Buff seems to mean "Blinded Nicholas," which seems to confirm the explanation I give of the Klaus customs. In Lithuania, mummers beat people on Dec. 24 (Globus, xxii., 239). Cf. Whipping Tom at Shrovetide (Ione, Table-book, 269).

Kloster, vii., 799 ; of. Mannhardt, Bk., p. 268.

Handelmann, loc. cit.

- Frazer, Golden Bough, ii., 38.

- Handelmann, p. 73, ff. p. 75; Pollux, loc. cit.

- $C f$. Globus, xvii., 24, where we find striking as a means of transferring sins to a scapegoat. 


\section{Animal Superstitions and Totemism.}

game of "Bock," 1 known in England as' stag or cockwarning. This game is also a survival of a human sacrifice that has taken the place of animal sacrifice. The parallel custom is that known as the "Loup vert" in France. ${ }^{2}$

Blind man's buff is not necessarily a survival of human sacrifice; there are facts which suggest that the cock has in some parts taken the place of a human victim. ${ }^{3}$. This, if correct, explains the wide distribution of the Hahnenschlag.

The Russian, Polish, and Bohemian names of blind: man's buff refer to the "old woman;" in the Kidlington lamb hunt," the Westphalian "Vogelschiessen," 5 and other customs, participation is confined to women. (Possibly this only points to a separation of the sexes.) We learn from Pomponius Mela ${ }^{6}$ that female priestesses officiated.

The connection of witches with customs involving the wearing of masks is borne out by other evidence. In the Romance languages masca and words apparently connected with it have the following meanings: (a) mask, (b) to blacken the face, (c) witch, (d) helmet. We know that blackening the face was a religious custom; if not a substitute for the mask it was at any rate a parallel custom. The helmet again was frequently surmounted by an animal's head, horns, ${ }^{7}$ \&c. We have therefore ground for supposing that the root of this series of words is the meaning mask. However this may be, it is clear that these meanings stand in some relation to each other, and that the resemblances are not due to mere chance. For in the old

Handelmann, loc. cit.

Liebrecht, p. 209.

Ehrenloup, Fries. Arch., ii., 6

4 . Fiii., 315 .

- De Gubernatis, p. $475 \mathrm{n}$.

- Lib., iii., c. 6.

'For refs. v. Arch. Rev., iii., 353. 
Scandinavian word grima and its derivatives we find exactly the same series. ${ }^{I}$ I need hardly point out how improbable it is that this should be a mere coincidence.

These facts seem to throw some light not only on the female element in witchcraft, but also on the belief that witches can assume the form of animals.

I have mentioned that the facts with regard to blind man's buff point to a custom of tribal sacrifice. This is borne out by the coincidence of the dialectical boundary in Westphalia with the use of the name "Blinde Maus" for blind man's buff. This boundary also coincides with the southern limit of the horse's heads on the peasants' houses. Into the ethnological questions thus raised I cannot now enter.

I have brought to your notice this evening facts which, I believe, conclusively prove the existence of an animal cult in Europe. From the distribution of the customs and beliefs we may infer that they were originally connected with the clan or the local group. This view is borne out by fact's which go to show that the sacrifice and ritual eating were the privilege of the kin alone. This conclusion will appear irresistible to those who accept the totemic interpretation of the Irish facts. I venture to think that the great mass of animal superstitions are best accounted for by the theory that they originated in a system of totemism differing in no essential respect from that which we find among the non-European races.

\section{BIBLIOGRAPHY.}

Am Urdsbrunnen, continued as

Am Urquell, Lunden, \&c., 1881, \&c.

Birlinger, Volkstümliches aus Schwaben. Freiburg. 1861-2.

' Grimm, pp. 197, 873 . 


\section{Animal Superstitions and Totemism.}

Brand, Popular Antiquities. London, I843.

Burne, Shropshire Folk-lore. London, 1884 , \&c.

Byegones relating to Wales and the Border Counties. Oswestry, $187 \mathrm{x}$, \&c.

Coremans, I'année de l'ancienne Belgique. Brussels, I844. Curtze, Volksüberlieferungen aus Waldeck. Arolsen, I860. Elton, Origins of English History. London, 1890.

Ethnographical Survey Report, Brit. Ass. Toronto meeting. Folk-Lore Record (F. L. R.), 1878-82. Journal (F. L. J.), $1883^{-89}$.

Folk-Lore $(F)$, 1890, \&c.

Gaslander, paper in Nyare Bidray till Kannedom om de Svenslea Landsmålen, Bik. I. 3. Uppsala, 1895.

Gregor, Folk-lore of the N.E. of Scotland. . London, $\mathrm{r} 88 \mathrm{I}$.

Grimm, Deutsche Mythologie 4te Auflage.

Grohmann, Aberglaube aus Böhmen. Prag, 1864 .

De Gubernatis, Die Tiere in der indo-germ. Mythologie.

Handelmann, Volks-u. Kinderspiele. Kiel, 1874.

Henderson, Folklore of Northern Counties. London, 1879.

Hone, Everyday Book. London, 1826 .

Jühling, Tiermedizin. : (Will appear shortly).

Kaindl, Die Huzulen. Wien, 1894.

Liebrecht, Gervase of Tilbury. Hanover, 1856 .

Mannhardt, Baumkultus. Berlin, 1876 .

Meier, E., Deutsche Sitten aus Schwaben. Stuttgardt, 1852.

Meyer, E. H., Germanische Mythologie. Berlin, 1890.

Montgomeryshire Collections (Mont. Coll.). London, 1867, et seq.

Muillenhof, Sagen, \&c., Schleswig-Holsteins. Kiel, 1845.

Napier, Folklore. Paisley, 1879.

De Nore, Coutumes des provinces de France. Paris, 1846 .

Notes and Queries ( $N$. and $Q$.$) . London, 1850, \& \mathrm{c}$.

Owen, Welsh Folklore. Oswestry, 1896.

Panzer, Beiträge zur d. Mythologie. München, 1848-55.

Peter, Volkstümliches aus öst. Schlesien. Troppau, 1865-73.

Pfannenschmid, Germanische Erntefeste. Hannover, 1878.

Reinsberg.Düringsfeld, Calendrier belge. - Brussels, r86r-2.

Rochholz, Deutsche Glaube u. Brauch. Berlin, 1867.

Rolland, Faune populaire. Paris, $1876-83$.

Das Kloster. 'Stuttgardt, I845-9. 
Schiller, Zum Tier-u. Kraüterbuch des Meckl. Volkes. Schwerin, I86I-4.

Schulenburg, Wendische Volkssagen. Leipzig, I880.

Schütze, Holsteinisches Idiotikon. Hamburg, 1800-6.

Strackerjan, Aberglaube aus Oldenburg. Oldenburg, 1867 .

Wander, Sprichwörter lexikon. Leipzig, I867-80.

Witzschel, Sagen aus Thüringen. Wien, r866-78.

Wuttke, Der deutsche Volksaberglaube. Hamburg, r860.

WoIf, Beiträge zur d. Mythologie. Göttingen, 1852-7.

Zeitschrift für Ethnologie. Berlin, 1869, \&c.

$-d$. Mythologie. Göttingen, $1853-9$.
des Vereins fur Volkskunde. Berlin, 189 I, \&c.

Note-May I appeal to those who are in a position to give me information, for localities in which the following animals are respected: badger, boar, eagle, glowworm, rabbit, sparrow, squirrel, wasp ; also notes of all fish-taboos. I also wish to know whether the following animals are killed in any of the ways enumerated under sacrifice: cormorant, cross-bill, partridge, peewit, quail, redstart, seal, sea-swallow, wagtail, weevil.

I have prepared a list of questions which I am circulating all over Europe. I shall be pleased to receive notes of. superstitions dealt with in the paper, and to send my questions to any one who will collect material. $-\mathrm{N}$. W. T. 